\title{
Chemical composition, vasorelaxant, antioxidant and antiplatelet effects of essential oil of Artemisia campestris L. from Oriental Morocco
}

\author{
Ikram Dib ${ }^{1}$, Marie-Laure Fauconnier ${ }^{2}$, Marianne Sindic ${ }^{3}$, Fatima Belmekki ${ }^{1}$, Asmae Assaidi ${ }^{1}$, Mohamed Berrabah $^{4}$,
} Hassane Mekhfi ${ }^{1}$, Mohammed Aziz ${ }^{1}$, Abdelkhaleq Legssyer ${ }^{1}$, Mohamed Bnouham ${ }^{1}$ and Abderrahim Ziyyat ${ }^{1 *}$

\begin{abstract}
Background: Artemisia campestris L. (Asteraceae) is a medicinal herb traditionally used to treat hypertension and many other diseases. Hence, this study is aimed to analyze the essential oil of $A$. campestris $L$ (AcEO) and to investigate the antiplatelet, antioxidant effects and the mechanisms of its vasorelaxant effect.

Methods: The chemical composition of AcEO was elucidated using GC/MS analysis. Then, the antioxidant effect was tested on DPPH radical scavenging and on the prevention of $\beta$-carotene bleaching. The antiplatelet effect was performed on the presence of the platelet agonists: thrombin and ADP. The mechanism of action of the vasorelaxant effect was studied by using the cellular blockers specified to explore the involvement of NO/GC pathway and in the presence of calcium channels blockers and potassium channels blockers.

Results: AcEO is predominated by the volatiles: spathulenol, ß-eudesmol and p-cymene. The maximal antioxidant effect was obtained with the dose $2 \mathrm{mg} / \mathrm{ml}$ of AcEO. The dose $1 \mathrm{mg} / \mathrm{ml}$ of AcEO showed a maximum antiplatelet effect of, respectively $49.73 \% \pm 9.54$ and $48.20 \% \pm 8.49$ on thrombin and ADP. The vasorelaxation seems not to be mediated via NOS/GC pathway neither via the potassium channels. However, pretreatment with calcium channels blockers attenuated this effect, suggesting that the vasorelaxation is mediated via inhibition of L-type $\mathrm{Ca}^{2+}$ channels and the activation of SERCA pumps of reticulum plasma.

Conclusion: This study confirms the antioxidant, antiplatelet and vasorelaxant effects of A.campestris $L$ essential oil. However, the antihypertensive use of this oil should be further confirmed by the chemical fractionation and subsequent bio-guided assays.
\end{abstract}

Keywords: Artemisia campestris L, GC/MS, Antioxidant, Antiplatelet, Vasorelaxant

\section{Background}

A. campestris $\mathrm{L}$. is an Asteraceae plant commonly known as field wormwood; it is a perennial undershrub (30$150 \mathrm{~cm}$ height), with branched and ascending brownishred stems. Leaves are green, the basal are 2-3 pinnatisects, the upper are simple. Inflorescence is an ovoid, heterogamous yellowish capitulum, with an involucral bracts; ray

\footnotetext{
* Correspondence: ziyyat@yahoo.fr; zabderrahim@hotmail.com 'Laboratoire de Physiologie, Génétique et Ethnopharmacologie URAC-40, Département de Biologie, Faculté des Sciences, Université Mohammed Premier, Oujda, Morocco

Full list of author information is available at the end of the article
}

flowers are female, pistillate and fertile, while the disk flowers are sterile, and functionally male [1-3]. In Morocco, A.campestris L. known as "Allal", is used as antidiabetic [4], to treat digestive, respiratory, metabolic, allergic problems [5, 6] and cutaneous problems [7]. This herb has many other ethnomedicinal uses like antihypertensive [8], emmenaguogue $[9,10]$, and well known for treatment of liver and kidney disorders [11-13] and as. Previous pharmacological studies proved that A. campestris $\mathrm{L}$. possesses antioxidant [14-20], antibacterial, antifungal [20-25], insecticidal [26-28], antitumor [14, 29-31], antivenin [32, 33], hepatoprotective, nephroprotective [34-37] 
and antidiabetic [38, 39] effects. Recently a clinical trial conducted on volunteers demonstrated that A.campestris L. enhanced $33.3 \%$ to $50 \%$ decrease in arterial pressure among hypertensive smoker patients [40]. In another study, the administration of A.campestris L. extract induced antihypertensive effect on envenomed hypertensive rats, and provoked $10 \%$ to $30 \%$ of hypertension drop, while the pretreatment with the herb extract prevented the rise of hypertension [32]. Nevertheless, no in-vitro study has been elaborated to evaluate the antihypertensive potential of this plant. In the aim to highlight the importance of this plant in the cardiovascular therapy, this study was performed to analyze the essential oil of $A$. campestris $\mathrm{L}$. (AcEO) growing in oriental Morocco, to investigate its vasorelaxant and subsequent mechanism of action and to determine its antiplatelet and antioxidant effects.

\section{Methods}

\section{Chemicals}

The following drugs and solvents were used in this study: $( \pm$ )-verapamil hydrochloride (Sigma Aldrich, China), (R)(-)-phenylephrine hydrochloride [Phe] (Sigma Aldrich, Germany), 1H-[1, 2, 4] Oxadiazolo[4,3-a]quinoxalin-1-one [ODQ] (Cayman Chemical, USA), 2, 2-diphenyl-1-picrylhydrazyl [DPPH] (Alfa Aesar, Germany), 4-aminopyridine [4-AP] (Alfa Aesar, Germany), adenosine 5'-diphosphate [ADP] (Sigma Aldrich, Germany), atropine (Sigma Aldrich, China), barium chloride dehydrate $\left[\mathrm{BaCl}_{2}\right]$ (AnalaR Normapur - VWR International, Belgium), calcium chloride dehydrate $\left[\mathrm{CaCl}_{2}, 2 \mathrm{H}_{2} \mathrm{O}\right]$ (Scharlau chemie, Spain), calmidazolium chloride (Sigma Aldrich, USA), carbamylcholine chloride [carbachol] (Sigma Aldrich, USA), citric acid (Farco chemical, Puerto Rico), D(+)glucose anhydrous (Sigma Aldrich_Riedel-de Haen, Germany), gelatin extrapur (HIMEDIA, India), glybenclamide (Sigma Aldrich, USA), hydroxocobalamin hydrochloride (Fluka, USA), indomethacin (Sigma Aldrich-Fluka, Italy), L-ascorbic acid (Sigma Aldrich, UK), linoleic acid (Sigma Aldrich, USA), magnesium sulfate $\left[\mathrm{MgSO}_{4}\right]$ (Sigma Aldrich, Germany), N $\omega$-NitroL-arginine methyl ester hydrochloride [L-NAME] (Sigma Aldrich, Switzerland), potassium di-hydrogen phosphate $\left[\mathrm{KH}_{2} \mathrm{PO}_{4}\right]$ (Panreac, Spain), Rp-8-Bromo- $\beta$ phenyl-1,N2-ethenoguanosine 3',5' -cyclicmonophosphorothioate sodium salt [Rp-8-Br-PET-cGMP] (Sigma Aldrich, Germany), sodium chloride $[\mathrm{NaCl}]$ (Sigma Aldrich_Riedel-de Haen, Denmark), sodium hydrogen carbonate $\left[\mathrm{NaHCO}_{3}\right]$ (Farco chemical, Puerto Rico], potassium chloride $[\mathrm{KCl}]$ (Sigma Aldrich_Riedel-de Haen, Germany), tetraethyl ammonium chloride hydrate [TEA] (Sigma Aldrich, USA), thapsigargin (Sigma Aldrich, Israel), thrombin, from bovine plasma (Sigma Aldrich, USA), trisodium citrate (Acros organics, belgium), Tween 40 (Sigma Aldrich, USA), $\beta$-carotene (Sigma Aldrich,
USA). The solvents utilized were: chloroform (Sigma Aldrich_Riedel-de Haen, Germany), diethyl ether (Sigma Aldrich, Germany), dimethyl sulfoxide [DMSO] (Sigma Aldrich Riedel-de Haen, Germany), methanol (Sigma Aldrich, Germany). All chemicals and solvents used were analytical grade. The stock solutions of ODQ, thapsigargin and $\mathrm{Rp}-8$ $\mathrm{Br}$-PET-cGMP were prepared in DMSO whereas indomethacin was prepared in $5 \%(\mathrm{w} / \mathrm{v})$ sodium bicarbonate solution. All other drugs were dissolved in distilled water.

\section{Plant material}

The aerial part of $A$. campestris $\mathrm{L}$. was collected at flowering stage in September 2012 in desert region of Figuig (in South-East of Morocco in the border area with Algeria). The species was identified by a botanist Pr. Aatika Mihamou from biology department, and a voucher specimen was deposited in the herbarium of the Faculty of Sciences, University Mohamed First (Oujda, Morocco) under the number HUMPOM-151.

\section{Preparation of A.campestris L. essential oil (AcEO)}

About $2 \mathrm{~kg}$ of the air-dried plant were used. For the extraction of the essential oil, the stems were thrown and the rest of the plant (leaves and flowers) was subjected to the hydrodistillation for $4 \mathrm{~h}$ by using Clevenger apparatus. The obtained oil was yellowish with characteristic odor; it was then separated from the distillate and stored in sealed glass vial at $4{ }^{\circ} \mathrm{C}$ until the moment of analysis. The essential oil was obtained in a yield of $0.4 \%(\mathrm{w} / \mathrm{w})$.

\section{Gas Chromatography (GC) analysis}

The GC analysis of AcEO was performed on an Agilent 5973 N GC-MS coupled to an Agilent 6890 gas chromatograph fitted with an injector at $250{ }^{\circ} \mathrm{C}$ (Splitless mode) and equipped with an HP-5MS capillary column coated with $5 \%$ phenyl-methyl siloxane ( $30 \mathrm{~m}$ length $\times 0.25 \mathrm{~mm}$ internal diameter $\times 0.25 \mu \mathrm{m}$ of film thickness, Agilent 19091S-433). The column pressure was set to $51.6 \times 103 \mathrm{~Pa}$. The oven temperature was held at $40{ }^{\circ} \mathrm{C}$ for $2 \mathrm{~min}$, and then programmed to $250{ }^{\circ} \mathrm{C}$ at a rate of $8{ }^{\circ} \mathrm{C} / \mathrm{min}$. Helium was used as the carrier gas at a flow rate of $1.1 \mathrm{ml} / \mathrm{min}$. Diluted sample in diethyl ether was manually injected.

\section{Gas-Chromatography-Mass Spectrometry (GC-MS) analysis} The GC-MS analysis of AcEO was performed on an Agilent 5973 N GC-MS coupled to an Agilent 6890 gas chromatograph fitted with an injector at $250{ }^{\circ} \mathrm{C}$ (Splitless mode) and equipped with an HP-5MS capillary column coated with $5 \%$ phenyl-methylsiloxane ( $30 \mathrm{~m}$ length $\times$ $0.25 \mathrm{~mm}$ internal diameter $\times 0.25 \mu \mathrm{m}$ of film thickness, Agilent 19091S-433). The column pressure was set to $51.6 \times 10^{3} \mathrm{~Pa}$. The oven temperature was held at $40{ }^{\circ} \mathrm{C}$ for $2 \mathrm{~min}$, and then programmed to $250{ }^{\circ} \mathrm{C}$ at a rate of $8{ }^{\circ} \mathrm{C} / \mathrm{min}$. Helium was used as the carrier gas at a flow 
rate of $1.1 \mathrm{ml} / \mathrm{min}$. The mass spectra (MS) were operated in electron impact mode $(70 \mathrm{eV})$ with the electron multiplier set at $1823.5 \mathrm{~V}$, and the MS data were acquired in scan mode. The peaks were quantified by calculating the percentage of the peak area of each component by comparison to the sum of the peaks of other compounds. The identification of the components was performed on the basis of chromatographic comparison of the recorded retention time with computed mass-spectrum data libraries (Pal600K and Wiley275).

\section{$\beta$-Carotene bleaching assay}

The $\beta$-Carotene bleaching test of AcEO was determined based on the standard procedure [41]. A volume of $1 \mathrm{ml}$ of chloroform solution of $\beta$-carotene $(0.1 \mathrm{mg} / \mathrm{ml})$ was added to a round flask containing $20 \mathrm{mg}$ of acid linoleic and $200 \mathrm{mg}$ of Tween 40. Chloroform was completely removed at $40{ }^{\circ} \mathrm{C}$ under vacuum, and $50 \mathrm{ml}$ of distilled water was slowly added and vigorously shaken. Three doses of AcEO and the reference standard Ascorbic acid $(0.1 ; 1$ and $2 \mathrm{mg} / \mathrm{ml})$ were dissolved in methanol. Aliquots $(200 \mu \mathrm{l})$ of AcEO and ascorbic acid were added to $5 \mathrm{ml}$ of $\beta$-carotene/linoleic acid emulsion. A control preparation was obtained by adding $200 \mu \mathrm{l}$ of methanol to $5 \mathrm{ml}$ of $\beta$-carotene/linoleic acid emulsion. Absorbance of the preparations was measured at $490 \mathrm{~nm}$ before and after $2 \mathrm{~h}$ of incubation in a water bath at $50{ }^{\circ} \mathrm{C}$. All trials were performed in triplicate. Antioxidative activity (AA $\%$ ) in percentages was calculated using the following formula:

$$
\mathrm{AA} \%=\left[\frac{\left(\mathrm{As}_{120}-\mathrm{Ac}_{120}\right)}{\left(\mathrm{Ac}_{0}-\mathrm{Ac}_{120}\right)}\right] \times 100
$$

Wher $\mathrm{Ac}_{0}$ is the absorbance of the control respectively measured before the incubation. $\mathrm{As}_{120}$ and $\mathrm{Ac}_{120}$ are the absorbance of the test and the control respectively measured after $2 \mathrm{~h}$ of incubation.

\section{DPPH radical scavenging assay}

The DPPH free radical scavenging activity of the EOs was evaluated as described by Senthilkumar et al. [42], with slight modifications. A volume of $1 \mathrm{ml}$ of $0.1 \mathrm{mM}$ of methanolic solution of the free radical 2,2-diphenyl-1picryl-hydrazyl (DPPH) was added to $1 \mathrm{ml}$ of increased doses of AcEO ranging from $0.1 \mathrm{mg} / \mathrm{ml}$ to $2 \mathrm{mg} / \mathrm{ml}$ previously dissolved in methanol. A control sample using methanol instead of AcEO was prepared. Ascorbic acid dissolved in methanol $(0.1-2 \mathrm{mg} / \mathrm{ml})$ was used as standard. The preparations were incubated for $30 \mathrm{~min}$ in obscurity at room temperature, then after, absorbance was measured at $517 \mathrm{~nm}$. Pure methanol was used as blank. Measurements were carried out in triplicate for each experiment.
Antioxidant activity was calculated using the equation:

$$
\% \text { scavenging }=\left[\frac{(\mathrm{Ac}-\mathrm{As})}{\mathrm{Ac}}\right] \mathrm{x} 100
$$

Where Ac is the absorbance of the control and As is the absorbance of the sample.

\section{Experimental animals}

Wistar rats and albino mice were provided from the local colonies of department of Biology (Faculty of Sciences, Oujda-Morocco); they were maintained in standard conditions, with a photoperiod of $12 \mathrm{~h}$ light and dark, and they were allowed to free access of water and food. All animals were cared for in compliance with the Guide for the Care and Use of Laboratory Animals, published by the US National Institutes of Health (NIH) [43].

\section{Acute toxicity}

Acute toxicity of AcEO was performed on the basis of the protocols conducted in previous similar studies [44, 45]. 25 albino mice were divided into five groups of five animals each. After $18 \mathrm{~h}$ of fasting with free access to water, the doses of $0.5,1,1.5$ and $2 \mathrm{mg} / \mathrm{kg}$ of AcEO were given orally to the mice, using a solution of gelatin $5 \%$ as vehicle. The control group was fed with $0.5 \%$ gelatin solution. The use of gelatin as an emulsifier is attributed to its non-toxic and nonirritability qualities as carrier molecule [46], besides its hydrophobic character that makes this macroprotein preferably used in pharmaceutical application and food industry as natural emulsifier and stabilizer [47, 48]. Also, gelatin is largely used as biodegradable macromolecule largely used for encapsulation of essential oils, mainly utilized in pharmaceutical and cosmetics to prevent eventual decomposition, evaporation or oxidation of the volatile oils [49]. Indeed, Sutaphanit and Chitprasert (2014) demonstrated that there was no significant interaction between gelatin and basil essential oil, along the encapsulation process [50]. General behavior and mortality were observed permanently during the four hours succeeding the dosing, and occasionally during the first $24 \mathrm{~h}$. The animals were monitored daily for any additional signs of toxicity and weekly for changes in body weight. Dead animals were sacrificed just after their death and the survived animals were sacrificed at the end of the experimentation by overdose of anesthesia by ethylic ether, and the organs were examined macroscopically for any toxicological alterations. The stomach was longitudinally incised by the greater curvature and ulceration or perforations of gastric mucosa were observed. The liver and kidneys have been weighted after been cleaned from connective tissues. 


\section{Platelet aggregation assay}

Wistar rats weighing 250-380 g were slightly anesthetized with ether. Abdominal aorta was catheterized and blood was collected in anti-coagulated tubes with a mixture of acid citric $(130 \mathrm{mM})$-trisodium citrate $(170 \mathrm{mM})$-glucose $4 \%(9: 1, \mathrm{v} / \mathrm{v})$. Washed platelets were prepared according to the experimental design reported by Gadi et al. [51]. A first centrifugation of blood (230 x g/15 min) was made and permitted to obtain a platelet rich plasma (PRP), which was centrifuged a second time $(400 \mathrm{x} \mathrm{g} / 15 \mathrm{~min})$ to obtain the platelet pellet. The platelets were then washed once with washing buffer $\left(\mathrm{NaCl} 137 \mathrm{mM}, \mathrm{KCl} 2.6 \mathrm{mM}, \mathrm{NaHCO}_{3}\right.$, $12 \mathrm{mM}, \mathrm{MgCl}_{2} 0.9 \mathrm{mM}$, glucose $5.5 \mathrm{mM}$, gelatin $0.25 \%$, $\mathrm{pH}$ 6.5), centrifuged for the last time $(400 \times g / 15 \mathrm{~min})$ and suspended in the final buffer with the following composition (mM): $\mathrm{NaCl} 137, \mathrm{KCl} 2.6, \mathrm{CaCl}_{2} 1.3, \mathrm{MgCl}_{2} 0.9$, glucose 5.5, Hepes 5, gelatin $0.25 \%, \mathrm{pH} 7.4$ ) in order to have a final platelet concentration of $5 \times 10^{5}$ cells $/ \mathrm{mm}^{3}$.

Platelet aggregation was performed using an aggregometer (Chrono-Log, Havertown, PA, USA). In a special tube containing $400 \mu \mathrm{l}$ of washed platelets at $37{ }^{\circ} \mathrm{C}$ with continual stirring at $1000 \mathrm{rpm}$, the aggregation was stimulated with aggregating agents, thrombin $(0.1 \mathrm{U} / \mathrm{ml})$ and ADP $(1 \mu \mathrm{M})$. For test studies, platelets were preincubated with different concentrations of AcEO (0.1, 0.5 and $1 \mathrm{mg} /$ $\mathrm{ml}$ ) for $1 \mathrm{~min}$ in the cuvette before the stimulation by the aggregating agents cited above. In all experiments, the platelet aggregation was then recorded during $5 \mathrm{~min}$. AcEO was dissolved in 0.5\% DMSO. Control experiments demonstrated that the concentrations of DMSO had no significant effect on the aggregatory effect.

\section{Determination of the mechanism underlying the vasorelaxant activity of AcEO}

The vascular tone was measured by referring to previously described procedure [52]. Wistar rats weighting 200-300 g were anesthetized with sodium pentobarbital $(0.1 \mathrm{ml} / 100 \mathrm{~g}$ body weight). The thoracic aorta was quickly and gently removed, cleaned of adherent connective tissue and cut into rings (3-4 $\mathrm{mm}$ in length). Rings were gently introduced between two stainless-steel hooks and placed in organ chamber (emka technologies, Paris) containing $11 \mathrm{ml}$ of Krebs solution gassed with 95\% $\mathrm{O}_{2}$ and $5 \% \mathrm{CO}_{2}$ and maintained at $37{ }^{\circ} \mathrm{C}$ and $\mathrm{pH}$ 7.4. One hook was connected to an isometric force transducer (emka technologies, Paris) and a tension of $1 \mathrm{~g}$ was applied to the vessels then they were allowed to stabilize for $30 \mathrm{~min}$. The composition of Krebs solution was as follows (mmol/L): $\mathrm{NaCl} \mathrm{119,} \mathrm{KCl} 4.7, \mathrm{CaCl}_{2} 2.6$, $\mathrm{MgSO}_{4}$ 1.2, $\mathrm{KH}_{2} \mathrm{PO}_{4} 1.2, \mathrm{NaHCO}_{3} 25$, and Glucose 11. Endothelial integrity was monitored by the percentage of relaxation evoked by carbachol $\left(10^{-4} \mathrm{M}\right)$ after a steady contraction was reached with phenylephrine $\left(10^{-6} \mathrm{M}\right)$. Rings with carbachol-induced relaxation less than $50 \%$ were discarded. AcEO was dissolved in final concentration of $0.5 \%$ DMSO. Control experiments showed that DMSO at $0.5 \%$ had no significant effect on the vascular tone.

\section{Vasorelaxant effect of AcEO on denuded aorta, and on intact aorta preincubated with Atropine and Calmidazolium}

In endothelium-intact aorta $(n=6)$, steady tension was evoked by Phen $(1 \mu \mathrm{M})$, then, AcEO $\left(10^{-4}-10^{-1} \mathrm{mg} / \mathrm{ml}\right)$ was cumulatively added to the Krebs solution. The contribution of endothelium, muscarinic receptor and subsequent $\mathrm{Ca}^{2+}{ }_{-} \mathrm{CaM}$ complex formation in the vasorelaxationinduced effect was checked out by the application of experiments described by Monteiro et al. [46]. Denuded rings $(n=6)$ were obtained by gentile rubbing of the lumen of aorta with a plier curved end, and the denudation was verified by the absence of any degree of relaxation caused by carbachol $\left(10^{-4} \mathrm{M}\right)$, then, AcEO (10-4-10-1 mg/ml) was cumulatively added. In another set of experiments, endothelium-intact rings were pre-incubated with the muscarinic receptor antagonist atropine $(1 \mu \mathrm{M} ; n=6)$ and $\mathrm{Ca}^{2+}$-Calmodulin binding to NOS blocker calmidazolium chloride $\left(10^{-3} \mu \mathrm{M} ; n=6\right)$ for 20 min prior the contraction with Phen $(1 \mu \mathrm{M})$, then, the cumulative concentration-response curves of AcEO were constructed and compared with those obtained with untreated rings.

\section{Vasorelaxant effect of AcEO on aorta preincubated with L-NAME, Hydroxycobalamin, ODQ and 8-RP-Br-PET-cGMP}

The endothelium-dependent vasorelaxant pathway was studied as described by Monteiro et al. [53]. Endotheliumintact rings were pre-incubated with the NO synthase inhibitor, L-NAME $\left(10^{-4} \mathrm{M} ; n=6\right)$, the NO scavenger, hydroxocobalamin $\left(3.10^{-5} \mathrm{M} ; n=6\right)$, the guanylyl cyclase inhibitor, ODQ $\left(10^{-5} \mathrm{M} ; n=6\right)$, and the competitive cGMP-dependent protein kinase G (PKG) inhibitor, Rp-8Br-PET-cGMP $\left(3.10^{-6} \mathrm{M} ; n=6\right)$ for $20 \mathrm{~min}$ prior the contraction with Phen $(1 \mu \mathrm{M})$, then, the cumulative concentration-response curves of AcEO were constructed and compared with those obtained with untreated rings.

\section{Vasorelaxant effect of AcEO on aorta preincubated with potassium channels blockers, TEA, 4-AP, BaCl2 and Glybenclamide}

The involvement of potassium channels in the vasorelaxant effect was assessed following the experimental procedure previously detailed, with some variations [54]. Endothelium-intact rings were incubated with the $\mathrm{Ca}^{2+}$ activated potassium channels, TEA $\left(10^{-2} \mathrm{M} ; n=6\right)$, the selective voltage-activated potassium channel $\left(\mathrm{K}_{v}\right)$ blocker, 4AP $\left(10^{-4} \mathrm{M} ; n=6\right)$, the selective inwardly-rectifying potassium channel blocker, $\mathrm{BaCl}_{2}\left(10^{-4} \mathrm{M} ; n=6\right)$, and the selective ATP-sensitive potassium channel blocker, glybenclamide $\left(10^{-5} \mathrm{M} ; n=6\right)$ for $20 \mathrm{~min}$ prior to contraction with 
Phen $(1 \mu \mathrm{M})$, then, the cumulative concentration-response curves of AcEO were constructed and compared with those obtained with untreated rings.

\section{Vasorelaxant effect of AcEO on aorta preincubated with Indomethacin, Thapsigargin and Verapamil}

Calcium channels and prostanoid mediated vasodilation was studied following the protocol detailed by $\mathrm{Li}$ et al. [55]. Endothelium-intact rings were pre-incubated with the nonselective cyclooxygenase inhibitor, indomethacin $\left(10^{-5} \mathrm{M}\right.$; $n=6$ ), and to explore the role of calcium channels in the vasorelaxant effect, endothelium-intact rings were incubated with the $\mathrm{Ca}^{2+}$-channel type VOC, verapamil $\left(10^{-5} \mathrm{M} ; n=6\right)$ and the endoplasmic reticulum $\mathrm{Ca}^{2+-} \mathrm{ATP}_{\text {ase }}$ (SERCA) inhibitor, thapsigargin $\left(10^{-7} \mathrm{M} ; n=6\right)$ for $20 \mathrm{~min}$ prior to contraction with phenylephrine $\left(10^{-6} \mathrm{M}\right)$, then, the cumulative concentration-response curves of AcEO were constructed and compared with those obtained with untreated rings.

\section{Vasorelaxant effect of AcEO on aorta precontracted with Phen $(1 \mu \mathrm{M})$ and $\mathrm{K}^{+}(80 \mathrm{mM})$ and comparative vasorelaxant effect of cumulative doses of ACEO and Verapamil on $\mathrm{K}^{+}(80 \mathrm{mM})$}

To confirm the involvement of voltage operated, and /or receptor operated calcium channels, and the enhancement of calcium release form internal stores in the vasodilator effect of AcEO, two sets of experiments were carried out as described by [56]. First, cumulative doses of the AcEO (0.1$100 \mu \mathrm{g} / \mathrm{ml}$ ) were added to aorta precontracted with both $\mathrm{K}^{+}$ $(80 \mathrm{mM})$ and Phen $(1 \mu \mathrm{M})$. In another set of experiments, a comparative profile of the vasorelaxant effect of ACEO cumulative doses $\left(10^{-4}-10^{-1} \mathrm{mg} / \mathrm{ml}\right)$ and verapamil $\left(10^{-8}-10^{-6}\right.$ M) was challenged on the aorta precontracted by $\mathrm{K}^{+}$ $(80 \mathrm{mM})$.

\section{Statistical analysis}

The data were expressed as the mean \pm standard error of mean (SEM). The results were analyzed using one-way and two-way analysis of variance (ANOVA), followed by Bonferroni's as a post-test. A value of $p<0.05$ was considered significant. The linear and nonlinear regression tests have been used as well. The chemical structures have been drawn by using the freeware version of the software ACD/ChemSketch (Freeware) 14.01.

\section{Results}

\section{Chemical analysis}

Chemical analyses (GC and GC/MS) of AcEO allowed the identification of 42 compounds. The chromatographic profile of the essential oil is shown in (Fig. 1). The oil has the spathulenol $(10.19 \%)$ as main component, followed by $\beta$-eudesmol (4.05\%), p-cymene $(3.83 \%), \delta$-cadinene (3.67\%), ß-pinene (2.82\%), caryophyllene oxide $(2.30 \%)$ and salvial-4(14)-en-1-one (2.51\%). The compounds mentioned in Fig. 1 were systematically found in all the samples. The chemical structures of the major chemical components found in AcEO are presented in (Fig. 2).

\section{$\beta$-Carotene bleaching assay}

The prevention of $\beta$-carotene bleaching with linoleic acid was similarly effective for AcEO $\left(\mathrm{AA}_{\max } \%=82.2 \% \pm 12.7\right)$ and the standard ascorbic acid ( $\mathrm{AA}_{\max } \%=86.65 \% \pm 6.45$ ) and the antioxidant effect of both tested substrates was higher than 50\% (Fig. 3a).

\section{DPPH radical scavenging assay}

The radical scavenging activity of AcEO against DPPH radical increased significantly in dose-dependent manner (Fig. 3b); the $\mathrm{EC}_{50}$ values calculated from the graph was $\mathrm{EC}_{50}=690 \mu \mathrm{g} / \mathrm{ml}$. However, the radical scavenging activity attributed to ascorbic acid seems to be more important, characterized by a linear and stable shape of the graph with a maximum of $96.23 \%$ of the antioxidant effect (AA \% higher than 50\%).

\section{Acute toxicity}

During the experiment, animals treated with $\mathrm{AcEO}$ at $2 \mathrm{~g} / \mathrm{kg}$, showed several signs of intoxication like: hyperactivity succeeded by asthenia, tremors, convulsion and irregular breathing, yet, all these signs disappeared after the first $24 \mathrm{~h}$. The same dose provoked minimal lethality (one animal dead), marked by an intense ulceration of gastric mucosa. However, no significant changes have been observed in organs and body weights monitored during 2 weeks succeeding AcEO injection.

\section{Antiplatelet effect}

AcEO (0.1, 0.5 and $1 \mathrm{mg} / \mathrm{ml}$ ) added to washed platelets inhibited aggregation triggered by thrombin $(0.1 \mathrm{U} / \mathrm{ml})$ and ADP $(1 \mu \mathrm{M})$. The dose $1 \mathrm{mg} / \mathrm{ml}$ showed a maximum inhibitory effect of, respectively, $49.73 \% \pm 9.54(p<0.01)$ and $48.20 \% \pm 8.49(p<0.05)$ on thrombin and ADP induced platelet aggregation. However the doses $0.1 \mathrm{mg} / \mathrm{ml}$ and $0.5 \mathrm{mg} / \mathrm{ml}$ of AcEO have no significant effect on the antiplatelet effect (Fig. 4).

\section{Determination of the mechanism underlying the vasorelaxant activity of AcEO \\ Vasorelaxant effect of AcEO on denuded aorta, and on intact aorta preincubated with Atropine and Calmidazolium} AcEO $(0.1-100 \mu \mathrm{g} / \mathrm{ml})$ abolished the contraction induced by phenylephrine on intact thoracic aorta, and induced $95.97 \% \pm 2.03$ of vasorelaxation. The vasorelaxant effect induced by AcEO on denuded aorta $(102.07 \% \pm 3.01 ; p>0.05)$, also, the pretreatment with calmidazolium $(97.07 \% \pm 3.29 ; p>0.05)$, blocker of calcium-calmodulin binding to NO synthase, did not affect the vasorelaxation induced by AcEO. However, the 


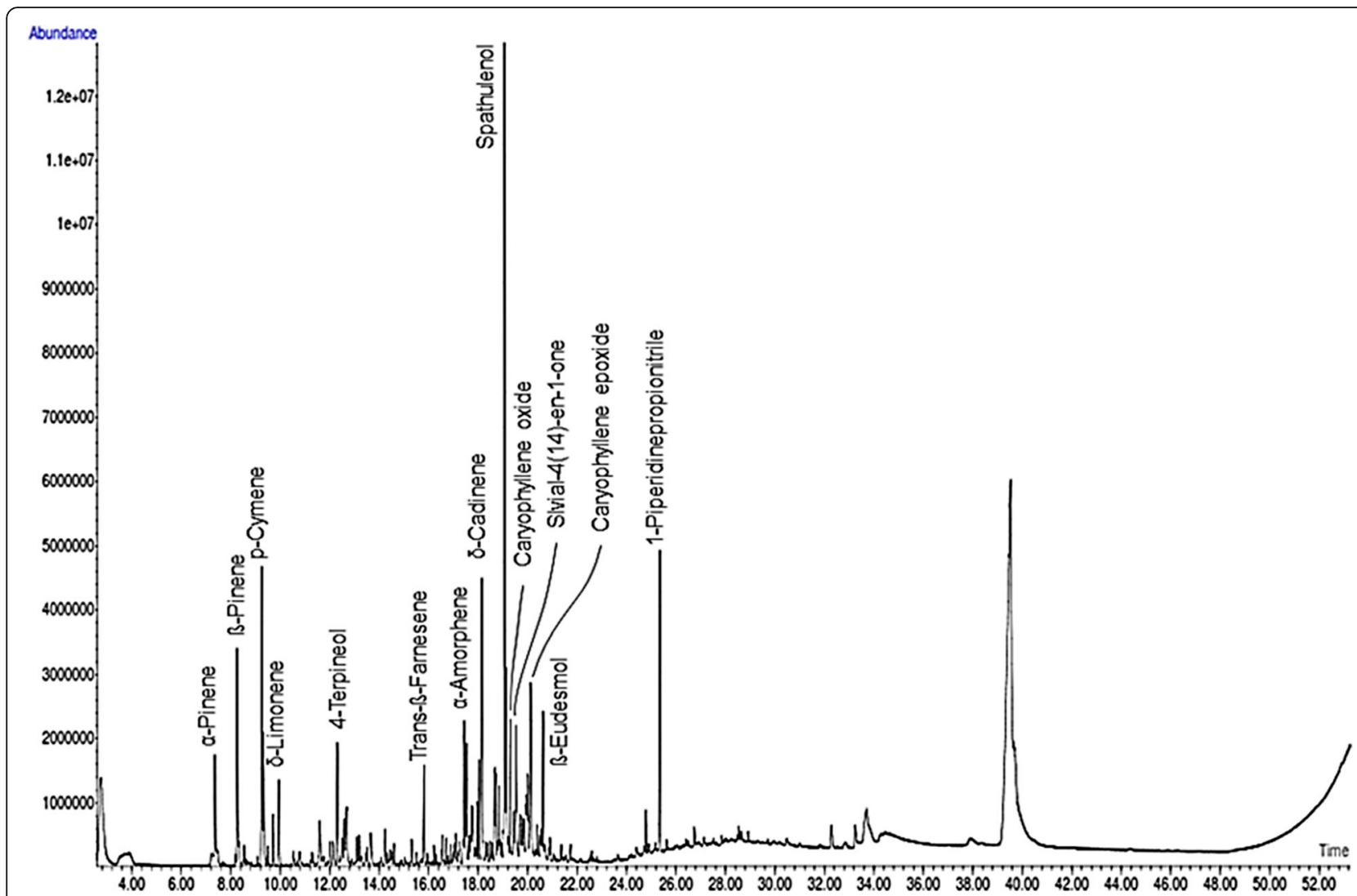

Fig. 1 GC-MS chromtogram of A. campestris L. essential oil (AcEO)

vasorelaxation provoked by AcEO on aorta precontracted with phenylephrine has been partially inhibited, when preincubated with the muscarinic receptor inhibitor, atropine $(85.69 \% \pm 6.56 ; p<0.05)$ (Fig. 5a).

\section{Vasorelaxant effect of AcEO on aorta preincubated with} L-NAME, Hydroxycobalamin, ODQ and 8-RP-Br-PET-CGMP No significant difference on the vasorelaxation effect of AcEO $(0.1-100 \mu \mathrm{g} / \mathrm{ml})$ on phenylephrine precontracted aorta have been observed in the presence of NO synthase inhibitor; L-NAME $(97.27 \% \pm 2.82 ; p>0.05)$, in the presence of NO scavenger; hydroxocobalamin $(93.99 \% \pm 2.32$; $p>0.05$ ), and in the presence of guanylyl cyclase inhibitor; ODQ $(92.26 \% \pm 3.91 ; p>0.05)$. However, relative inhibitory effect AcEO-induced vasorelaxation have been observed in the presence of the competitive cGMPdependent protein kinase $\mathrm{G}$ (PKG) inhibitor; $\mathrm{Rp}-8-\mathrm{Br}$ PET-cGMP $(87.86 \% \pm 4.28 ; p<0.05)$ (Fig. $5 \mathrm{~b})$.<smiles>CC1=CCC2CC1C2(C)C</smiles>

a-Pinene<smiles>CC1=CC2C(=C(C)CCC2C(C)C)CC1</smiles>

8-Cadinene<smiles>C=C1CCC2CC1C(C)(C)C2CCCC</smiles><smiles>C=C1CCC2C(C)C2(C)CC1C1CCC(C)(O)C1</smiles>

Spathulenol<smiles>Cc1ccc(C(C)C)cc1</smiles><smiles>[10BH][14CH3]</smiles><smiles>C=C1CCC2OC2CCC2C1CC2(C)C</smiles>

Caryophyllene oxide<smiles>C=C1CCCC2CCC(C(C)(C)C)CC12</smiles>

B-Eudesmol<smiles>C=C(C)C1CC=C(C)CC1</smiles>

8-Limonene

Fig. 2 Chemical structures of volatiles compounds of A. campestris L. essential oil (AcEO) 

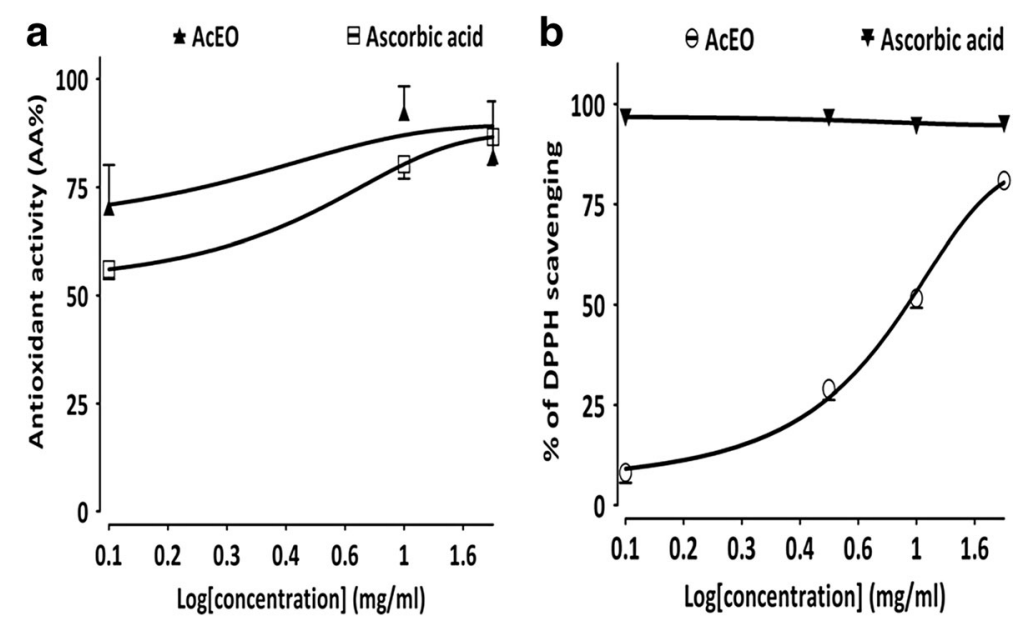

Fig. 3 Antioxidant effect of A.campestris L. essential oil (AcEO) and ascorbic acid on (a) the scavenging of 2, 2(diphenyl-1-picryhydrazyl (DPPH) radical (b) the prevention of $\beta$-carotene bleaching and; Values are mean $\pm \operatorname{SEM}, n=3$, and analyzed with linear regression test

Vasorelaxant effect of AcEO on aorta preincubated with potassium channels blockers, TEA, 4-AP, BaCl2 and Glybenclamide

Pretreatment of aorta with potassium channels blockers; TEA $(98.91 \% \pm 3,73 ; p>0.05), 4-\mathrm{AP}(98.05 \% \pm 2.96$; $p>0.05), \mathrm{BaCl}_{2}(103.52 \% \pm 2.47 ; \mathrm{p}>0.05)$ and glybenclamide $(99.55 \% \pm 2.66 ; p>0.05)$, showed no significant changes in AcEO $(0.1-100 \mu \mathrm{g} / \mathrm{ml})$ induced-vasorelaxation (Fig. 6a).

\section{Vasorelaxant effect of ACEO on aorta preincubated with Indomethacin, Thapsigargin and Verapamil}

Pretreatment of aorta with cyclooxygenase inhibitor; indomethacin $(92.95 \% \pm 2.73 ; p>0.05)$ did not produce any significant difference of vasorelaxation induced by AcEO precontracted with phenylephrine. Therefore, aorta preincubated with endoplasmic reticulum calciumATPase inhibitor; thapsigargin $(45.34 \% \pm 6.58 ; p<0.001)$, and calcium channel type VOC blocker; verapamil
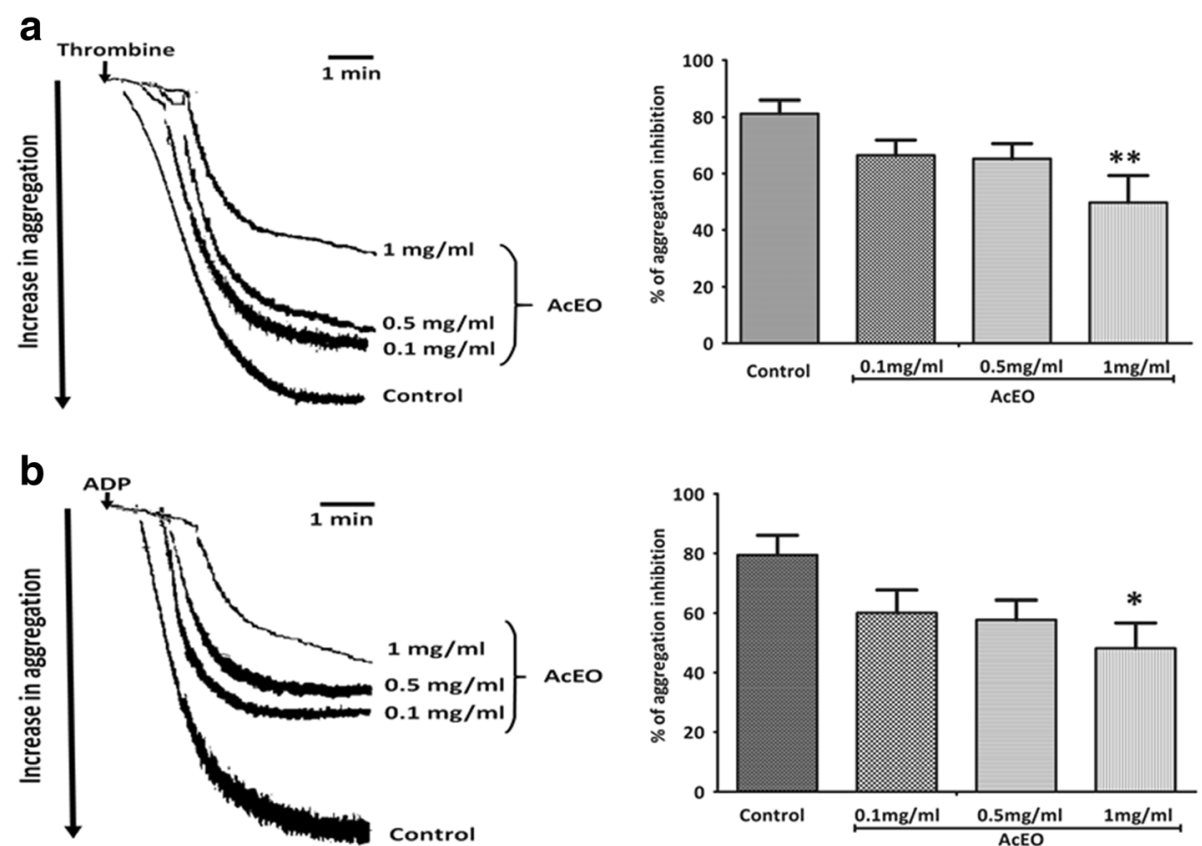

Fig. 4 The originaltrcing and percentage of aggregation inhibition of $0.1,0.5$ and $1 \mathrm{mg} / \mathrm{ml}$ of A. campestris L. essential oil (AcEO) on thrombin (a) and $\operatorname{ADP}(\mathbf{b})$ induced platelet aggregation. Values are mean $\pm \mathrm{SEM}, n=6$, analysed with one way ANOVA followed by Bonferroni's post-test; $p^{*}<0.005$ vs control and ${ }^{* *}<0.01$ vs control 

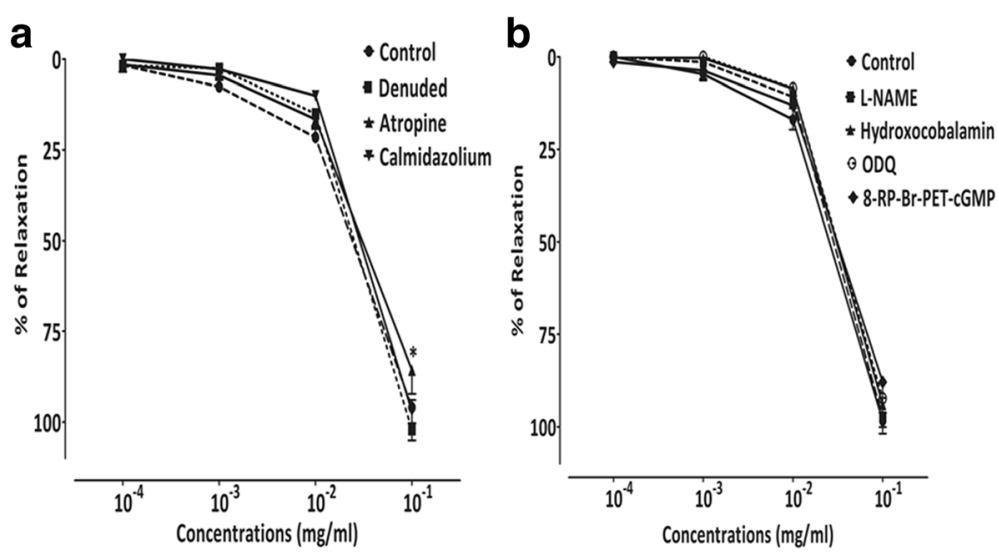

Fig. 5 Concentration-response curves of the vasorelaxant effect of $A$. campestris $L$. (AcEO) on (a) isolated aorta pre-contracted with phenylephrine $10^{-6} \mathrm{M}$, on denuded aorta and on aorta pre-incubated with Atropine and Calmidazolium, (b) with L-NAME, Hydroxocobalamin, ODQ and 8-RP-BrPET-cGMP. Values are mean $\pm \mathrm{SEM}, n=6$, and analyzed with two way ANOVA followed by Bonferroni's post-test; * $p<0.05$ vs control

$(48.12 \% \pm 8.21 ; p<0.001)$ produced a sub-maximum inhibitory effect of vasorelaxation induced by AcEO (0.1-100 $\mu \mathrm{g} / \mathrm{ml})$ (Figs. 6b and 7).

\section{Vasorelaxant effect of ACEO on aorta precontracted with Phen (1 $\mu \mathrm{M})$ and $\mathrm{K}^{+}(80 \mathrm{mM})$ and comparative vasorelaxant effect of cumulative doses of ACEO and Verapamil on $\mathrm{K}^{+}$ (80 mM)}

As shown in Fig. 8, AcEO triggered a concentrationdependent vasodilation against Phen $(1 \mu \mathrm{M})$ and $\mathrm{K}^{+}$ $(80 \mathrm{mM})$ induced vasocontractions, with respective $\mathrm{EC}_{50}$ value of $0.005 \mathrm{mg} / \mathrm{ml}(n=6)$ and $0.019 \mathrm{mg} / \mathrm{ml}(n=6)$. In parallel, AcEO and verapamil administered in increasing doses to the plateau of $\mathrm{K}^{+}(80 \mathrm{mM})$, showed a similar vasorelaxant profile with respective $E_{\max }$ values of $(97,04 \%+4,08 ; n=6)$ and $(94,97 \%+3,35 ; n=6)$ (Fig. 9).

\section{Discussion}

Many studies have reported the chemical composition of essential oil of $A$. campestris L. growing in different countries. However, this study represents the first report about the essential oil of $A$. campestris L. (AcEO) existing in Morocco. As shown in Fig. 1, GC/MS analysis of essential oil of A.campestris L. resulted on the determination of spathulenol (10.19\%) as the most prominent compound, followed by $ß$-eudesmol (4.05\%), p-cymene (3.83\%), $\delta$-cadinene (3.67\%), and $ß$-pinene (2.82\%). These findings are consistent with our new published paper, which confirmed the similar chemical profile of A.campestris L. essential oil collected in the flowering stage of the year 2014 [57]. By comparison to the literature data, our findings are partially in accordance with a study conducted in Iran by Kazemi et al. [58], in which the predominated components of essential oil obtained
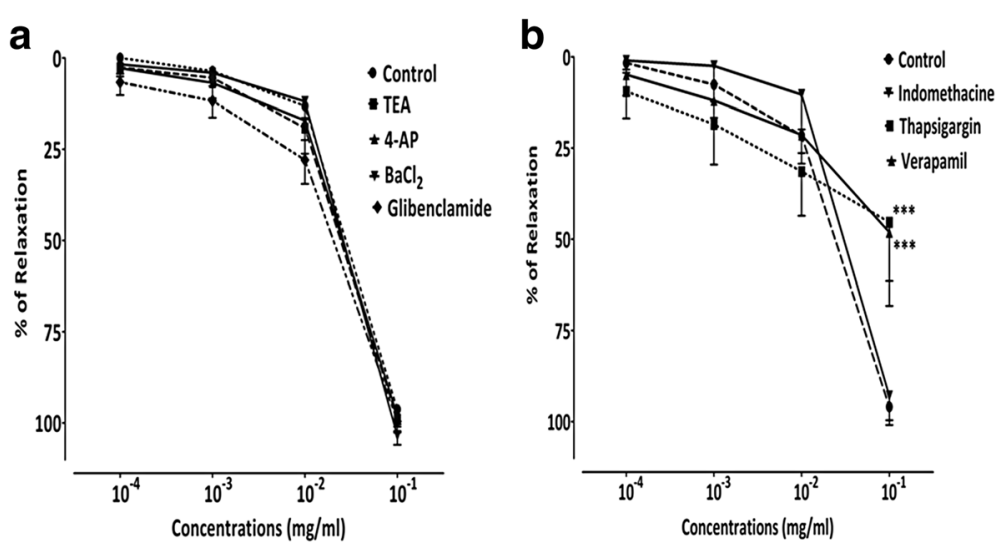

Fig. 6 Concentration-response curves of the vasorelaxant effect of A. campestris L. (AcEO) on (a) isolated aorta pre-contracted with Phen $1 \mu M$, and in the presence of TEA, 4-AP, $\mathrm{BaCl}_{2}$ and Glibenclamide, and in the presence of $(\mathbf{b})$ Thapsigargin, Verapamil and Indomethacin. Values are mean $\pm \mathrm{SEM}, n=6$, and analyzed with two way ANOVA followed by Bonferroni's post-test; ${ }^{* *} p<0.001$ vs control 

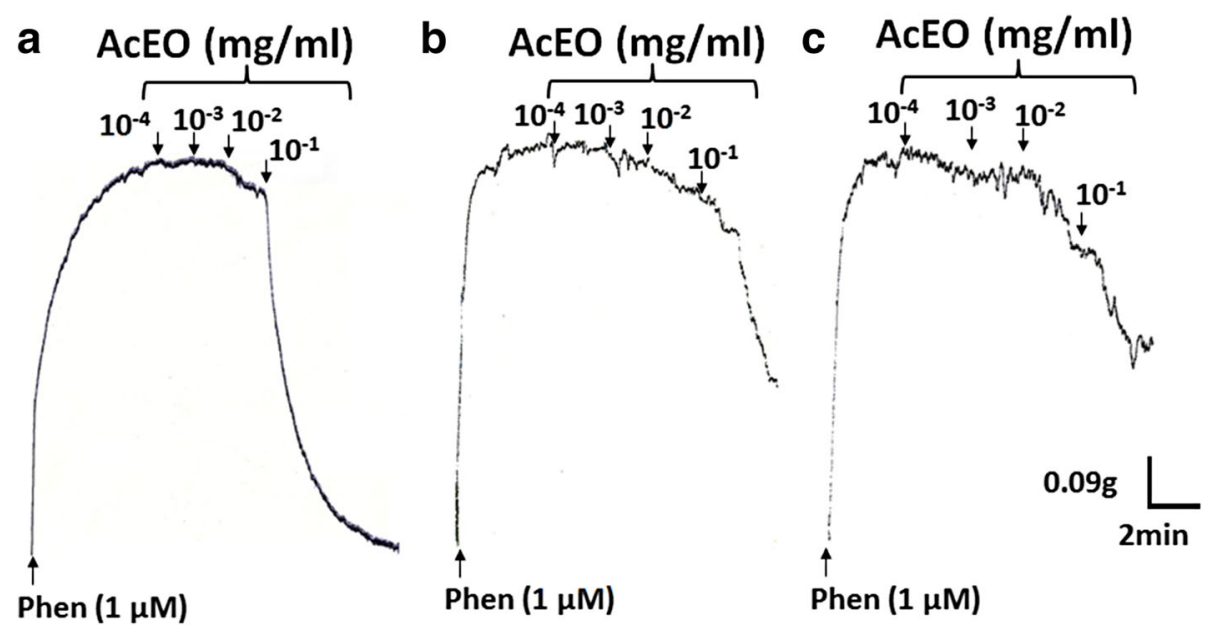

Fig. 7 Original tracing showing the vasorelaxant effect of A. campestris L. essential oil (AcEO) on isolated aorta pre-contracted with Phen $1 \mu M(\mathbf{a})$ and in the presence of Verapamil (b) and Thapsigargin (c)

from the flowers, leaves and stems of A.campestris L. were $\alpha$-pinene (23-29.2\%) and spathulenol (15.8-29.2\%). Another work revealed the existence of the major volatiles spathulenol and $\beta$-pinene in essential oil of $A$. campestris L. from Serbia [2]. Previous studies reported the existence of two chemotypes of $A$. campestris L. essential oil occurring in different localities; the most relevant chemotype consists mainly in $\beta$-pinene alone or together with $\alpha$-pinene occurring mainly in Tunisia [14, 59-62], Algeria [10, 63-65], and Southern Ural [66], while the other chemotype was characterized by the volatiles: tremetone and capillen, detected in essential oil of $A$. campestris L. growing in Turkey [24]. Moreover, it is known that the species A.campestris L. presents great variability in its essential oil composition due to the existence of different subspecies from different localities. In France, A.campestris subsp. glutinosa has the main terpenes: $\gamma$-terpinene and capillene [27, 67], while, the same subspecies from Italy presented the major compounds: $\beta$-pinene, germacrene D and bicyclogermacrene [68]. Other studies
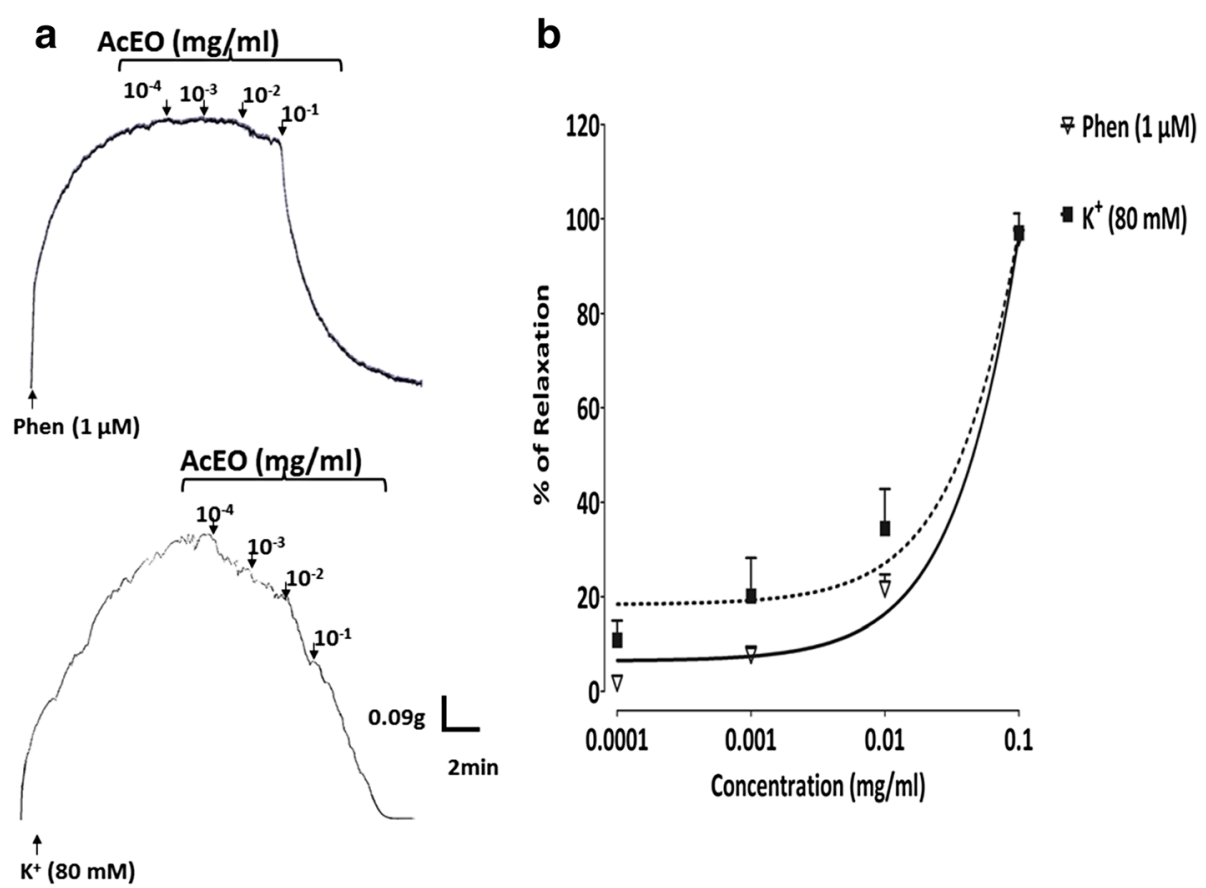

Fig. 8 The originaltrcing (a) and the concentration-response curves (b) of the vasorelaxant effect of $A$. campestris L. essential oil (AcEO) on Phen $(1 \mu \mathrm{M})$ and on $\mathrm{K}^{+}(80 \mathrm{mM})$-induced contraction. Values are mean $\pm \mathrm{SEM}, n=6$, and analyzed with non linear regression test 

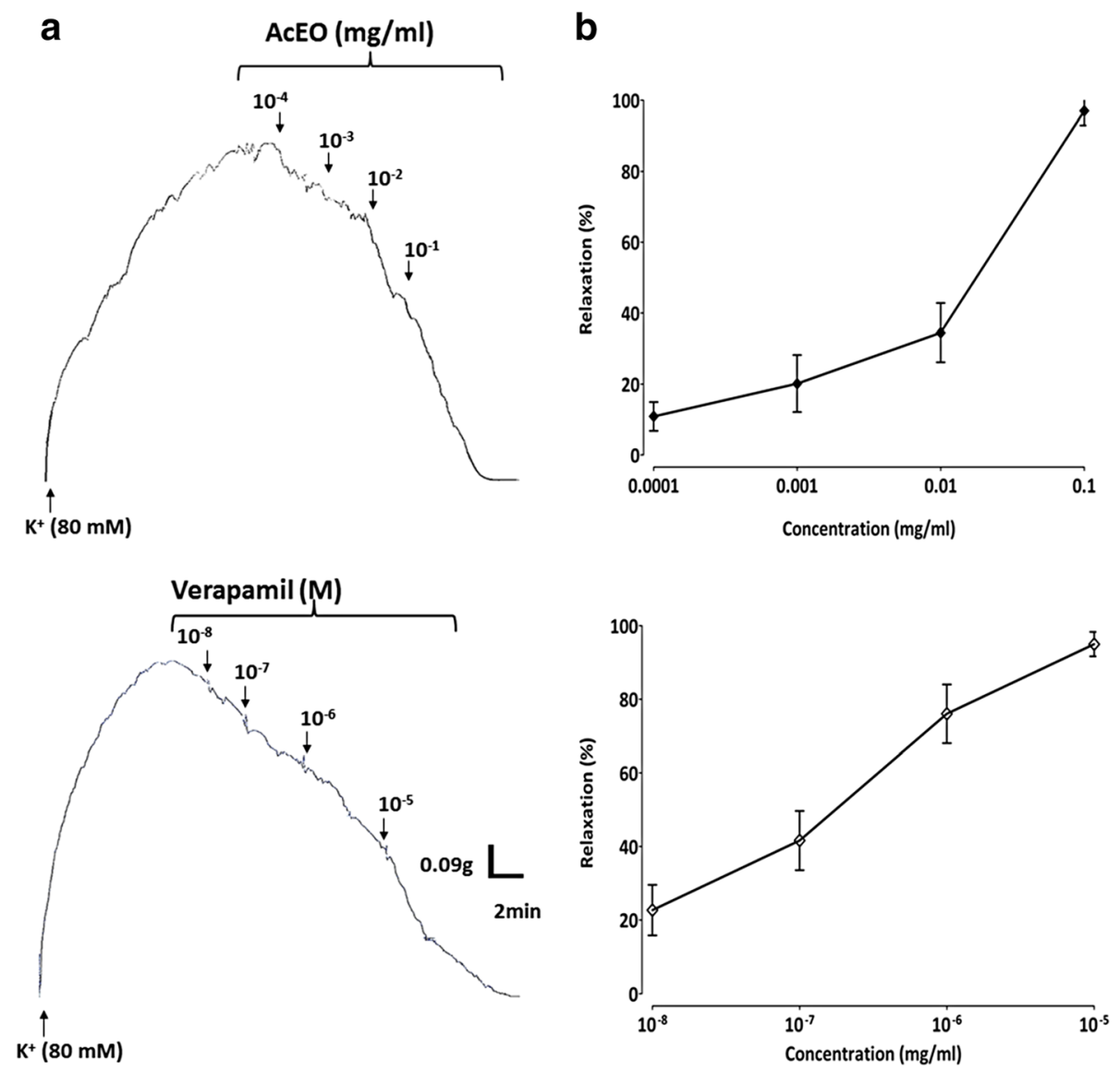

Fig. 9 The original tracing (a) and the concentration-response curves (b) of the vasorelaxant effect of A. campestris L. essential oil (AcEO) and Verapamil on $\mathrm{K}^{+}(80 \mathrm{mM})$-induced contraction. Values are mean $\pm \mathrm{SEM}, n=6$, and analyzed with linear regression test

reported that A.campestris subsp. campestris essential oil from Lithuania and Poland possesses the main components: caryophyllene oxide, Z-falcarinol, germacrene $D, \beta$-pinene, $\gamma$-curcumene, $\gamma$-humulene [69-72]. The oils of other subspecies, maritima from Portugal and borealis from Italy were rich in $\beta$-pinene, cadin4-en-7-ol, caryophyllene oxide and $\alpha$-pinene [73-75]. Taking into account all these data, the species $A$. campestris L. can be segregated into many chemotypes based on the variation of the essential oil composition, which may lead to consider the species growing in the arid region of Eastern Morocco as a new chemotype characterized by the spathulenol as the major compound.

Antioxidant effect of AcEO evaluated on the scavenging of DPPH radical $\left(\mathrm{EC}_{50}=690 \mu \mathrm{g} / \mathrm{ml}\right)$ seems to be considerable, though, the absence of a dose-response effect with both AcEO and ascorbic acid seems to be confusing. Indeed, the DPPH test reproducibility is controversial, since it is limited by its lack of specificity; the DPPH assay is not a competitive reaction, because the purple color of the DPPH radical can be easily lost via either hydrogen atom transfer (HAT) or reduction through single electron transfer (SET). Otherwise, the steric accessibility of DPPH radical represent the major limitation of this test that confers a more accessibility of the small molecules to the radical site and which may consequently have a higher antioxidant effect. On the other hand, a large brand of antioxidant compounds with peroxyl radicals may react slowly or may even be inert in reaction to DPPH which is a nitrogen radical in the first place [76, 77]. All these artefacts may interfere with the actual antioxidant effect of the AcEO and the ascorbic acid used as reference, which may blind their effective antioxidant effect and omit the dose-response efficiency of both substrates. On the other hand, the DPPH radical scavenging obtained with AcEO seems to be very important when compared to that observed with the essential oil obtained from the aerial part $\left(\mathrm{IC}_{50}=94500 \mu \mathrm{g} / \mathrm{ml}\right)$ [14] and leaves $\left(\mathrm{IC}_{50}=1874 \mu \mathrm{g} / \mathrm{ml}\right)$ of Tunisian A.campestris $\mathrm{L}$. [59]. However, the essential oil extracted from leaves of A.campestris L. occurring in Algeria appears to have more efficient antioxidative potential on DPPH 
radical $\left(\mathrm{IC}_{50}=39 \mu \mathrm{g} / \mathrm{ml}\right)$ [17]. On the other hand, AcEO prevented $82.2 \%$ of $\beta$-carotene bleaching with lineolate substrate, which is in agreement with study reported by Akrout et al. [14].

The oral acute toxicity of AcEO resulted on an $\mathrm{LD}_{50}$ value greater than $2 \mathrm{~g} / \mathrm{kg}$, body weight. The essential oil caused a minimal lethality witnessed by one dead animal in the group fed by $2 \mathrm{~g} / \mathrm{kg}$, body weight, and which was marked with an intense perforations and ulcerations of gastric mucosa that probably causes the death. Otherwise, there were any adverse effects on the body weight or the organs weights monitored during the 15 days of the study. On the basis of the present data AcEO is considered as toxic at $2 \mathrm{~g} / \mathrm{kg}$ due to gastric lesions induced. Additional studies about the toxicity of $A$. campestris $\mathrm{L}$. are available, showing that the intraperitoneal administration of aqueous extract to mice showed an earlier toxicity with an $\mathrm{LD}_{50}=2.5 \mathrm{~g} / \mathrm{kg}$ of body weight [39]. Furthermore, an acute toxicity test of the essential oil of A.campestris L. on brine shrimp larvae (Artemia sp.) gave the median lethality dose ranging from 15 to $20 \mu \mathrm{g} / \mathrm{ml}$ [69]. Concerning the platelet aggregation induced by both agonists thrombin $(0.1 \mathrm{U} / \mathrm{ml})$ and ADP $(1 \mu \mathrm{M})$, AcEO was able to reduce it about $50 \%$; so it can be postulated that this oil may interact with the site of action of ADP and thrombin and hence interrupting their cellular signaling and antagonizing the aggregation process. This results seems to be very considerable, by reference to a previous study conducted by our team, where the pharmaceutical anti-aggregant reference acetylsalicylic acid $(1 \mathrm{mg} / \mathrm{ml})$ induced a total inhibition of the aggregability caused by thrombin but at a quite high dose $(1 \mathrm{mg} / \mathrm{ml})$, if compared with our study when thrombin is tested at the dose $0.1 \mathrm{mg} / \mathrm{ml}$ [78]. It has been reported that platelet activation and aggregation are participating in the emergence of hypertension in different ways [79]. Platelets activation in hypertension can be explained by several mechanisms, among which the auto-degranulation that leads to activation of platelets exposed to increased shear force as result of high blood pressure [80]. Activated platelets released endogenous mediators like ADP which is known as a platelet aggregating agent that interact with two platelets receptors: Gq-coupled $\mathrm{P}_{2} \mathrm{Y}_{1}$ that induces a transient rise in free cytoplasmic calcium and Gi-coupled $\mathrm{P}_{2} \mathrm{Y}_{12}$ that provoke inhibition of adenylyl cyclase. Both pathways are necessary to elicit platelet aggregation [81]. Thrombin is a another platelet agonist that enhance aggregation; in fact, thrombin induced platelets activation via proteaseactivated receptors (PARs) that has a protein Gqaction, enhancing activation of phospholipase $\mathrm{C}$ (PLC $\beta$ ), which hydrolyzes phosphatidylinositol 4,5 bisphosphate $\left(\mathrm{PIP}_{2}\right)$, that promote the production of second messenger $\mathrm{IP}_{3}$, which contributes to the increase in intracellular $\mathrm{Ca}^{2+}$ through mobilization from internal stores and influx from the extracellular department. The increase in intracellular $\mathrm{Ca}^{2+}$ regulates many events leading to platelet aggregation [81].

The vasorelaxant effect of AcEO is obvious, since it succeeded to abolish the contraction triggered by phenylephrine, and produced a complete relaxation of aorta. Indeed, it is well evidenced that phenylephrine stimulates vascular contractions by acting through stimulation of $\alpha_{1}$ adrenergic receptors, which will provoke the conversion of phosphatidylinositol to inositol 1 , 4, 5-triphosphate, leading to the release of $\mathrm{Ca}^{2+}$ from the intracellular stores [82]. In light of these finding, we aimed to highlight the mechanism of action of this vasorelaxant effect, by exploring many cellular signaling mechanisms, including endothelium-dependent and independent pathways.

The endothelium is a highly specialized layer of luminal blood vessel, playing a key role in the vasorelaxation, mediated mainly by the release of endothelium-derived vasodilators, like nitric oxide (NO) and prostacyclin [83-86]. By reference to our data, AcEO vasorelaxant effect appears to be endothelium-independent, since the vascular response persisted after removal of the endothelium. In the endothelial cell, the signalling mechanism responsible for muscarinic receptor-dependent NO production involves $\mathrm{Ca}^{2+}$ and calmodulin-dependent activation of eNOS [87]. Once produced, calcium/calmodulin complex $\left(\mathrm{Ca}^{2+} / \mathrm{CaM}\right)$ enhance the dissociation of eNOS from caveolae, which become catalytically active and induces $\mathrm{NO}$ production [88]. The NO, as released by endothelial cells, increased cGMP levels in the smooth muscle, activated PKG, and phosphorylated the same vascular smooth muscle proteins, which induces a decrease in intracellular calcium concentration and a subsequent vasorelaxation [89]. To check up the involvement of this pathway in the vasorelaxant action of AcEO, aorta was submitted to specific inhibitors and blockers of endothelium mediators that triggered the vasorelaxant action like atropine (nonselective antagonist muscarinic receptors), calmidazolium $\left(\mathrm{Ca}^{2+}\right.$-calmodulin binding to NOS blocker), L-NAME (NOS inhibitor), hydroxocobalamin (NO scavenger), ODQ (inhibitor of soluble guanylyl cyclase) and protein kinase G (PKG) inhibitor (Rp-8-Br-PET-cGMPs). Even though, the vasorelaxation was not affected in the presence of these drugs, which confirm that endothelium and specifically NO-GC-PKG pathway was not involved in this effect.

Another pathway of vasorelaxation endotheliumdependent has been studied; it's about the COX product: $\mathrm{PGI}_{2}$ which is recognized for its potential ability to relax vascular smooth muscle [90] via activation of second messenger cAMP [91]. Hence, the possible role of $\mathrm{PGI}_{2}$ seems to be ruled out, because the pretreatment of aorta with, indomethacin, the COX 
inhibitor, did not change the vasorelaxant effect induced by AcEO.

In vascular smooth muscle cell membrane, the opening of potassium channels $\left(\mathrm{K}^{+}\right)$enhance an increase in $\mathrm{K}$ + efflux, provoking membrane potential $(E m)$ hyperpolarization and subsequent closure of voltage-activated calcium $\left(\mathrm{Ca}^{2+}\right)$ channels, causing a decrease of intracellular $\mathrm{Ca}^{2+}$ mobilization followed by a vasodilation [92]. In our experiments, the treatment of aorta with potassium channels blockers did not change the vasodilator action induced by AcEO, which suggests that the observed effect is potassium channel-independent. Besides $\mathrm{K}^{+}$channels, $\mathrm{Ca}^{2+}$ channels contribute to the relaxant effect of resistant vessels. The $\mathrm{Ca}^{2+}$ influx into vascular smooth muscle have two preponderant pathways: one is an L-type $\mathrm{Ca}^{2+}$ channel and the other is a store-operated $\mathrm{Ca}^{2+}$ channel (STOC). L-type calcium channels are the main gate of $\mathrm{Ca}^{2+}$ mobilization from extracellular space during cell excitation. The $\mathrm{Ca}^{2+}$ influx through L-type $\mathrm{Ca}^{2+}$ channels is the determinant of intracellular calcium level in the vascular smooth muscle and hence the key parameter of contraction [93]. Hence, the calcium antagonism via L-type calcium channel is a recognized as a mechanism of vasorelaxation [94]. A decrease in $\mathrm{Ca}^{2+}$ levels into sarcoplasmic reticulum (SR) triggers refilling of cytoplasmic $\mathrm{Ca}^{2+}$ in the $\mathrm{SR} \mathrm{Ca}^{2+}$ store through sarco/ endoplasmic reticulum $\mathrm{Ca}^{2+}$ ATPase (SERCA) pump and decreasing $\mathrm{Ca}^{2+}$ influx from STOC, which consequently decreases intracellular $\mathrm{Ca}^{2+}$ and enhance the vasorelaxation [95]. We performed separate experiments with the blockers of SERCA pump (thapsigargin) and Ltype calcium channels (verapamil). As result, we found that AcEO-vasorelaxation induced was decreased by $50 \%$ with both drugs. In addition, AcEO inhibited KCLinduced contraction, and subsequently reduced the $\mathrm{Ca}^{2}$ ${ }^{+}$-induced contraction in aortic rings exposed to $\mathrm{KCl}$, and this effect was similar to that observed with increasing doses of verapamil, a known calcium channel blocker and a vasorelaxant drug, which confirms that AcEO acts by blocking the L-type calcium channels. However, A.campestris L. oil also inhibited Pheninduced contraction, suggesting that it attenuated $\mathrm{Ca}^{2+}$ influx through receptor-operated $\mathrm{Ca}^{2+}$ channels as well.

In the matter of fact, the antagonizing effect of verapamil and thapsigargin remains debatable, since a persistent vasorelaxation of AcEO was maintained after the pretreatment with both drugs. These results suggest that the vasodilator effect of AcEO may involve the synergetic contribution of both calcium channels; otherwise, AcEO may act concomitantly, on both channels, by blocking VOCC channels, and by activating the SERCA pump, both mechanisms will together participate in an additive and/or synergetic manner to decrease the intracellular levels of calcium leading to a subsequent vasorelaxation.

\section{Conclusion}

Herein, we have shown that the chemical profile drawn for essential oil of $A$. campestris L. growing in Eastern Morocco reveal a new chemotype related to this region and spathulenol was identified as the predominant component of this oil. The pharmacological properties attributed to AcEO, like antioxidant, antiplatelet and vasorelaxant effects seem to be very interesting. The present work provide, also, evidence about the signaling mechanism of vasorelaxation induced by AcEO, showing that essential oil acts via L-type calcium channels and SERCA pumps to reduce intracellular calcium, and consequently triggering a sustained vasodilation.

\section{Abbreviations}

4-AP: 4-Aminopyridine; AA: Antioxidative activity; $\mathrm{Ac}_{0}$ : Control absorbance before incubation; $A c_{120}$ : Control absorbance after 2 hours incubation; AcEO: Artemisia campestris L. essential oil; ADP: Adenosine diphosphate; $\mathrm{As}_{120}$ : Sample absorbance after 2 hours incubation; ATP: Adenosine triphosphate; $\mathrm{BaCl}_{2}$ : Barium chloride; $\mathrm{Ca}^{2+}-\mathrm{CaM}$ : Calcium-calmodulin complex; CAMP: Cyclic adenosine monophosphate; CGMP: Cyclic guanosine monophosphate; COX: Cyclooxygenase; DMSO: Diméthylsulfoxyde; DPPH: 2, 2-Diphenyl-1picrylhydrazyl; $\mathrm{EC}_{50}$ : Half maximal effective concentration; $\mathrm{EC}_{\text {max }}$ : Effective concentration that gives the maximal effect; Em: Membrane potentiel; eNOS: Endothelial nitrous oxide synthase; GC: Guanylyl cyclase; GC-MS: Gas chromatography-mass spectrometry; Gq-coupled P2Y: Purinergic receptor P2Y, G-protein coupled, 1; Gq-coupled P2Y 12: purinergic receptor P2Y, G-protein coupled, 12; IP: Inositol trisphosphate; Kv: Voltage activated potassium channel; L-NAME: N $\omega$-Nitro-L-arginine methyl ester hydrochloride; MS: Mass spectrometry; NO: Nitrous oxide; NOS: Nitrous oxide synthase; ODQ: $1 \mathrm{H}-[1,2,4]$ Oxadiazolo[4,3-a]quinoxalin-1-one; PARs: Protease activated receptors; $\mathrm{PGI}_{2}$ : Prostacyclin; Phe: Phenylephrine; $\mathrm{PIP}_{2}$ : Phosphatidyl inositol diphosphate; PKG: Protein kinase G; PLC $\beta$ : Phospholipase C $\beta$; PRP: Platelet rich plasma; Rp-8-Br-PET-cGMPS: Rp-8-Bromo- $\beta$-phenyl-1,N2-ethenoguanosine 3',5'cyclic monophosphorothioate sodium salt; SERCA: Sarco/endoplasmic reticulum $\mathrm{Ca}^{2+}$-ATPase; SR: Sarcoplasmic reticulum; STOC: Store operated calcium channel; TEA: Tetraethylammonium; VOC channels: Voltage-operated calcium channels.

\section{Acknowledgements}

This research was supported by a training program of "Healthy Food for Life" project sponsored by International Research Staff Exchange Scheme (IRSES), we are grateful to their support during the training period. We are thankful to Professor Mihamou Aatika for the botanical identification of A. campestris L. We address our thanks to Franck Michels and Danny Trisman, technicians affiliated to Laboratory of Chimie Générale et Organique, Gembloux Agro-Bio Tech, Univesrité de Lièrge_Belgium, for the thechincal assistance, and to Mostafa Bedraoui technician from laboratory of Physiologie, Génétique et Ethnopharmacologie_Faculté des Sciences, Université Mohamed Premier, Oujda_Morocco, for the reliable care of animals breeding.

\section{Funding}

The authors declare that they have received no funding for the research reported.

\section{Availability of data and materials}

All data and materials supporting the conclusion in this paper are described and included in this published article.

\section{Author's contributions}

ID conducted the animal studies, biochemical assays, performed the statistical analysis and wrote the manuscript. AZ oversaw all the work, approved the experimental design, analyzed and interpreted the results and revised the manuscript. AA contributed to the achievement of the isolated aorta experiments. FB and HM carried out the antiplatelet test and helped to improve the manuscript. MLF and MS performed GC and GC/MS analyses of the essential oil and participated in the correction of the manuscript. $\mathrm{MB}$ gave some instructions and recommendations to improve the GC/MS 
analysis part. MB, MA and AL helped in the correction of the manuscript. All the authors read the manuscript and approved the final version.

\section{Competing interests}

The authors declare that they have no competing interests.

\section{Consent for publication}

Not applicable.

\section{Ethics approval and consent to participate}

All animals were cared for in compliance with the Guide for the Care and Use of Laboratory Animals, published by the US National Institutes of Health(National Institutes of Health. 2011. Guide for the Care and Use of Laboratory Animals. Eight Edition). Also this study followed principles in the Declaration of Helsinki (http://www.wma.net/en/policy/b3.html).

\section{Author details}

'Laboratoire de Physiologie, Génétique et Ethnopharmacologie URAC-40, Département de Biologie, Faculté des Sciences, Université Mohammed Premier, Oujda, Morocco. ${ }^{2}$ Unité de Chimie Générale et Organique, Gembloux Agro-bio Tech, Université de Liège, Gembloux, Belgium. ${ }^{3}$ Laboratoire Qualité et Sécurité des Produits Alimentaires, Gembloux Agro-Bio Tech, Université de Liège, Gembloux, Belgium. ${ }^{4}$ Laboratoire de Chimie du Solide Minéral et Analytique, Département de Chimie, Faculté des Sciences, Université Mohammed Premier, Oujda, Morocco.

\section{Received: 21 June 2016 Accepted: 21 January 2017}

\section{Published online: 31 January 2017}

\section{References}

1. Quézel P, Santa S. Artemisia L. (Armoise). In: Nouvelle Flore de l'Algérie et des Régions Désertiques Méridionales. Tome Ilth ed. Paris: C.N.R.S; 1962. p. 988-90.

2. Chalchat J-C, Cabassu P, Petrovic S, Maksimovic Z, Gorunovic M. Composition of essential oil of Artemisia campestris L. from Serbia. J Essent Oil Res. 2003; 15(4):251-53.

3. Tutin TG, Heywood VH, Burges NA, Valentine DH. Artemisia L. In: Flora Europea, volume 4, Plantaginaceae to Composite (and Rubiaceae). 4th ed. Cambridge: Cambridge University Press; 1976. p. 178-86.

4. Bnouham M, Mekhfi H, Legssyer A, Ziyyat A. Ethnopharmacology forum medicinal plants used in the treatment of diabetes in Morocco. Int J of Diabetes Metab. 2002:10:33-50.

5. Fakchich J, Elachouri M. Ethnobotanical survey of medicinal plants used by people in Oriental Morocco to manage various ailments. J Ethnopharmacol. 2014;154(1):76-87.

6. Bammou M, Daoudi A, Sellam K, El Rhaffari L, Ibijbijen J, Nassiri L. Étude Ethnobotanique des Astéracées dans la Région Meknès-Tafilalet (Maroc)[Ethnobotanical Survey of Asteraceae Family used in Meknes-Tafilalet Region (Morocco)]. Int J Innov Appl Stud. 2015;13(4):789-815.

7. El Hassani M, Douiri E, Bammi J, Zidane L, Badoc A, Douira A. Plantes médicinales de la Moyenne Moulouya (Nord-Est du Maroc). Ethnopharmacologia. 2013;50:39-53.

8. Boudjelal A, Henchiri C, Sari M, Sarri D, Hendel N, Benkhaled A, Ruberto G. Herbalists and wild medicinal plants in M'Sila (North Algeria): An ethnopharmacology survey. J Ethnopharmacol. 2013;148(2):395-402.

9. Hammiche V, Maiza K. Traditional medicine in Central Sahara: pharmacopoeia of Tassili N'ajjer. J Ethnopharmacol. 2006;105(3):358-67.

10. Boulanouar B, Abdelaziz G, Aazza S, Gago C, Miguel MG. Antioxidant activities of eight Algerian plant extracts and two essential oils. Ind Crops Prod. 2013:46:85-96.

11. Minami M, Suzuki M, Hosokawa K, Kondo S, Oka K, Shibata T. Preliminary survey of taxonomical problems, pharmacognostical characteristics, and chloroplast DNA polymorphisms of the folk medicinal herb Artemisia campestris from the Ryukyu Islands, Japan. J Nat Med. 2010;64(2):239-44

12. Ben Sassi A, Harzallah-Skhiri F, Aouni M. Investigation of some medicinal plants from Tunisia for antimicrobial activities. Pharm Biol. 2007;45(5):421-28.

13. Benchelah A-C, Bouziane H, Maka M. Fleurs du Sahara, arbres et arbustes, voyage au coeur de leurs usages avec les Touaregs du Tassili. Phytothérapie. 2004:2(6):191-97.

14. Akrout A, Gonzalez LA, El Jani H, Madrid PC. Antioxidant and antitumor activities of Artemisia campestris and Thymelaea hirsuta from southern Tunisia. Food Chem Toxicol. 2011;49(2):342-47.
15. Sebai H, Jabri M-A, Souli A, Hosni K, Selmi S, Tounsi H, Tebourbi O, Boubake S, El-Benna J, Sakly M. Protective effect of Artemisia campestris extract against aspirin-induced gastric lesions and oxidative stress in rat. RSC Adv. 2014:4(91):49831-41.

16. Tlili N, Elfalleh W, Hannachi H, Yahia Y, Khaldi A, Ferchichi A, Nasri N. Screening of natural antioxidants from selected medicinal plants. Int J Food Prop. 2013; 16(5):1117-26.

17. Bakchiche B, Gherib A. Activités antioxydantes des polyphenols extraits de plantes médicinales de la pharmacopée traditionnelle d'Algérie [Antioxidant activities of polyphenol extracts from medicinal plants in Algerian traditional pharmacopoeia]. Int J Innov Appl Stud. 2014;9(1):167-72.

18. Djidel S, Khennouf S. Radical scavenging, reducing power, lipid peroxidation inhibition and chelating properties of extracts from Artemisia campestris $L$. Aerial parts. Ann Res Rev Biol. 2014;4(10):1691-702.

19. Djeridane A, Yousfi M, Brunel JM, Stocker P. Isolation and characterization of a new steroid derivative as a powerful antioxidant from Cleome arabica in screening the in vitro antioxidant capacity of 18 Algerian medicinal plants. Food Chem Toxicol. 2010;48(10):2599-606.

20. Megdiche-Ksouri W, Trabelsi N, Mkadmini K, Bourgou S, Noumi A, Snoussi M, Barbria R, Tebourbi O, Ksouri R. Artemisia campestris phenolic compounds have antioxidant and antimicrobial activity. Ind Crops Prod. 2015;63:104-13.

21. Webster D, Taschereau P, Belland RJ, Sand C, Rennie RP. Antifungal activity of medicinal plant extracts; preliminary screening studies. J Ethnopharmacol. 2008;115(1):140-46.

22. Zabka M, Pavela R, Gabrielova-Slezakova L. Promising antifungal effect of some Euro-Asiatic plants against dangerous pathogenic and toxinogenic fungi. J Sci Food Agric. 2011;91(3):492-97.

23. Karabegović I, Nikolova M, Veličković D, Stojičević S, Veljković V, Lazić M. Comparison of antioxidant and antimicrobial activities of methanolic extracts of the Artemisia sp. recovered by different extraction techniques. Chin J Chem Eng. 2011;19(3):504-11.

24. Baykan Erel \$̧, Reznicek G, Şenol SG, Karabay Yavaşoğulu NÜ, Konyalioğlu S, Zeybek AU. Antimicrobial and antioxidant properties of Artemisia L. species from western Anatolia. Turk J Biol. 2012;36(1):75-84.

25. El Abed N, Guesmi F, Mejri M, Marzouki M, Ben Hadj Ahmed S. Phytochemical screening and assessment of antioxidant, antibacterial and cytotoxicty activities of five Tunisian medicinal plants. Int J Pharm Res Biosci. 2014;3(4):770-89.

26. Pavela R. Larvicidal effects of some Euro-Asiatic plants against Culex quinquefasciatus Say larvae (Diptera: Culicidae). Parasitol Res. 2009;105(3):887-92.

27. Masotti $V$, De Jong L, Moreau X, Rabier J, Laffont-Schwob I, Thiéry A. Larvicidal activity of extracts from Artemisia species against Culex pipiens $L$. mosquito: Comparing endemic versus ubiquist species for effectiveness. C R Biol. 2012:335(1):19-25.

28. Pascual-Villalobos M, Robledo A. Screening for anti-insect activity in Mediterranean plants. Ind Crops Prod. 1998;8(3):183-94.

29. Réthy B, Csupor-Löffler B, Zupkó I, Hajdú Z, Máthé I, Hohmann J, Rédei T, Falkay G. Antiproliferative activity of Hungarian Asteraceae species against human cancer cell lines. Part I Phytother Res. 2007;21(12):1200-08.

30. Aicha N, Ines S, Mohamed BS, Ines B, Soumaya K, Kamel G, Mohamed N, Imed C, Mohamed H, Leila C-G. Chemical composition, mutagenic and antimutagenic activities of essential oils from (Tunisian) Artemisia campestris and Artemisia herba-alba. J Essent Oil Res. 2008;20(5):471-77.

31. Erel ŞB, Şenol SG, Köse FA, Ballar P. In vitro cytotoxic properties of six Artemisia L. species. Turk J Pharm Sci. 2011;8(3):247-52.

32. Ben Nasr H, Hammami TS, Mahmoudi L, Zeghal K. Aqueous leaves extract of Artemisia campestris inhibition of the scorpion venom induced hypertension. J Med Plant Res. 2014;8(13):538-42.

33. Memmi A, Sansa G, Rjeibi I, El Ayeb M, Srairi-Abid N, Bellasfer Z, Fekhih A. Use of medicinal plants against scorpionic and ophidian venoms. Arch Inst Pasteur Tunis. 2007;84(1-4):49-55.

34. Saoudi M, Allagui MS, Abdelmouleh A, Jamoussi K, El Feki A. Protective effects of aqueous extract of Artemisia campestris against puffer fish Lagocephalus lagocephalus extract-induced oxidative damage in rats. Exp Toxicol Pathol. 2010;62(6):601-05.

35. Barkat L, Boumendjel A, Saoudi M, El Feki A, Messarah M. Artemisia campestris leaf aqueous extract alleviates methidathion-induced nephrotoxicity in rats. In J Pharm Sci Rev and Res. 2015;32(2):200-09.

36. Sefi M, Troudi A, Hamida F, Soudani N, Boudawara T, Zeghal N. Protective effects of Artemisia campestris upon fenthion-induced nephrotoxicity in adult rats and their progeny. Gen Physiol Biophys. 2013;32(4):577-88 
37. Sefi M, Bouaziz H, Soudani N, Boudawara T, Zeghal N. Fenthion induced-oxidative stress in the liver of adult rats and their progeny: Alleviation by Artemisia campestris. Pestic Biochem Physiol. 2011;101(2):71-9.

38. Sefi M, Fetoui H, Soudani N, Chtourou Y, Makni M, Zeghal N. Artemisia campestris leaf extract alleviates early diabetic nephropathy in rats by inhibiting protein oxidation and nitric oxide end products. Pathol Res Pract. 2012;208(3):157-62.

39. Sefi M, Fetoui $H$, Makni M, Zeghal N. Mitigating effects of antioxidant properties of Artemisia campestris leaf extract on hyperlipidemia, advanced glycation end products and oxidative stress in alloxan-induced diabetic rats. Food Chem Toxicol. 2010;48(7):1986-93.

40. Ben-Nasr H, Salama M, Ksouda K, Zeghal KM, Hammami S. Hemodynamic effects of aqueous extract of Artemisia campestris in adult men. J Appl Pharm Sci. 2014;4(04):38-42.

41. Kulisic T, Radonic A, Katalinic V, Milos M. Use of different methods for testing antioxidative activity of oregano essential oil. Food Chem. 2004:85(4):633-40.

42. Senthilkumar A, Venkatesalu V. Chemical constituents, in vitro antioxidant and antimicrobial activities of essential oil from the fruit pulp of wood apple. Ind Crops Prod. 2013;46:66-72.

43. National Institutes of Health. Guide for the Care and Use of Laboratory Animals. Eightth ed. Washington: The National Academies Press; 2011. https://grants.nih.gov/grants/olaw/Guide-for-the-Care-and-Use-ofLaboratory-Animals.pdf.

44. do Rosário Martins M, Arantes S, Candeias F, Tinoco MT, Cruz-Morais J. Antioxidant, antimicrobial and toxicological properties of Schinus molle L. essential oils. J Ethnopharmacol. 2014;151(1):485-92.

45. Guilhon CC, Raymundo LJ, Alviano DS, Blank AF, Arrigoni-Blank MF, Matheus ME, Cavalcanti SC, Alviano CS, Fernandes PD. Characterisation of the antiinflammatory and antinociceptive activities and the mechanism of the action of Lippia gracilis essential oil. J Ethnopharmacol. 2011;135(2):406-13.

46. Sundar S, Kundu J, Kundu SC. Biopolymeric nanoparticles. Sci. Technol. Adv. Mater. 11 (1):014104. doi:10.1088/1468-6996/11/1/01410.

47. Zarai Z, Balti R, Sila A, Ali YB, Gargouri Y. Helix aspersa gelatin as an emulsifier and emulsion stabilizer: functional properties and effects on pancreatic lipolysis. Food Funct. 2016;7(1):326-36.

48. Mariod AA, Fadul H. Review: gelatin, source, extraction and industrial applications. Acta Sci Pol Technol Aliment. 2013;12(2):135-47.

49. Bakry AM, Abbas S, Ali B, Majeed H, Abouelwafa MY, Mousa A, Liang L. Microencapsulation of Oils: A Comprehensive Review of Benefits, Techniques, and Applications. Compr Rev Food Sci Food Saf. 2016;15(1):143-82.

50. Sutaphanit $\mathrm{P}$, Chitprasert P. Optimisation of microencapsulation of holy basil essential oil in gelatin by response surface methodology. Food Chem. 2014; 150:313-20.

51. Gadi D, Bnouham M, Aziz M, Ziyyat A, Legssyer A, Legrand C, Lafeve FF, Mekhfi $\mathrm{H}$. Parsley extract inhibits in vitro and ex vivo platelet aggregation and prolongs bleeding time in rats. J Ethnopharmacol. 2009;125(1):170-74

52. Skiker M, Mekhfi H, Aziz M, Haloui B, Lahlou S, Legssyer A, Bnouham M, Ziyyat A. Artemisia herba-alba Asso relaxes the rat aorta through activation of NO/ CGMP pathway and KATP channels. J Smooth Muscle Res. 2010;46(3):165-74.

53. Monteiro FS, Silva AC, Martins IR, Correia AC, Basílio IJ, Agra MF, Bhattacharyya $J$, Silva BA. Vasorelaxant action of the total alkaloid fraction obtained from Solanum paludosum Moric. (Solanaceae) involves NO/cGMP/PKG pathway and potassium channels. J Ethnopharmacol. 2012;141(3):895-900.

54. Adaramoye OA, Anjos RM, Almeida MM, Veras RC, Silvia DF, Oliveira FA, Cavalcante KV, Araújo IG, Oliveira AP, Medeiros IA. Hypotensive and endothelium-independent vasorelaxant effects of methanolic extract from Curcuma longa L. in rats. J Ethnopharmacol. 2009;124(3):457-62.

55. Li X, Kim HY, Cui HZ, Cho KW, Kang DG, Lee HS. Water extract of Zanthoxylum piperitum induces vascular relaxation via endothelium-dependent NO-cGMP signaling. J Ethnopharmacol. 2010;129(2):197-202.

56. Gilani AH, lqbal J, Yasinzai M, Aziz N, Khan A. Antispasmodic and vasodilator activities of Morinda citrifolia root extract are mediated through blockade of voltage dependent calcium channels. BMC Complement Altern Med. 2010;10(1):1.

57. Dib I, Mihamou A, Berrabah M, Mekhfi H, Aziz M, Legssyer A, Bnouham M, Ziyyat A. Identification of Artemisia campestris L. subsp. glutinosa (Besser) Batt. from Oriental Morocco based on its morphological traits and essential oil profile. J Mater Environ Sci. 2017;8(1):180-87.

58. Kazemi M, Tabatabaei-Anaraki M, Rustaiyan A, Motevalizadeh A, Masoud S. Chemical composition of the essential oils obtained from the flower, leaf and stem of Artemisia campestris L. from Iran. J Essent Oil Res. 2009;21(3):197-99.
59. Akrout A, El Jani H, Amouri S, Neffati M. Screening of antiradical and antibacterial activities of essential oils of Artemisia campestris L., Artemisia herba alba Asso, \& Thymus capitatus Hoff. Et Link. growing wild in the southern of Tunisia. Rec Res Sci Tech. 2010;2(1):29-39.

60. Akrout A, Chemli R, Chreif I, Hammami M. Analysis of the essential oil of Artemisia campestris L. Flavour Fragr J. 2001;16(5):337-39.

61. Akrout A, Neffati M, Chemli R, Aouni M, Jerraya R, Dammak M, Dar A. Composition chimique et activités biologiques de l'huile essentielle d'Artemisia campestris L. Revue des Régions Arides. 2007;(1):231-40.

62. Akrout A, Chemli R, Simmonds M, Kite G, Hammami M, Chreif I. Seasonal variation of the essential oil of Artemisia campestris L. J Essent Oil Res. 2003; 15(5):333-36.

63. Belhattab R, Boudjouref M, Barroso J, Pedro L, Figueiredo A. Essential oil composition from Artemisia campestris grown in Algeria. Adv Environ Biol. 2011;5(2):429-32.

64. Dob T, Dahmane D, Berramdane T, Chelghoum C. Chemical composition of the essential oil of Artemisia campestris. L. from Algeria. Pharm Biol. 2005; 43(6):512-14.

65. Houicher A, Hechachna H, Özoğul F. In vitro determination of the antifungal activity of Artemisia campestris essential oil from Algeria. Int J Food Prop. 2015:19(8):1749-56.

66. Khalilov L, Paramonov E, Khalilova A, Odinokov V, Muldashev A, Baltaev U, Dzhemilev U. Identification and biological activity of volatile organic compounds emitted by plants and insects. IV. Composition of vapor isolated from certain species of Artemisia plants. Chem Nat Prod. 2001;37(4):339-42.

67. Juteau F, Masotti V, Bessière J-M, Viano J. Compositional characteristics of the essential oil of Artemisia campestris var. glutinosa. Biochem Syst Ecol. 2002:30(11):1065-70

68. Bellomaria B, Valentini G, Biondi E. Chemotaxonomy of Artemisia variabilis Ten. and A. campestris L. ssp. glutinosa (Ten.) Briq. et Cavill. (Asteraceae) from Italy. J Essent Oil Res. 2001;13(2):90-4.

69. Judzentiene A, Budiene J, Butkiene R, Kupcinskiene E, Laffont-Schwob I, Masotti V. Caryophyllene oxide-rich essential oils of Lithuanian Artemisia campestris ssp. campestris and their toxicity. Nat Prod Commun. 2010;5(12):1981-84.

70. Judzentiene A, Budiene J. Variability of Artemisia campestris L. essential oils from Lithuania. J Essent Oil Res. 2014:26(5):328-33.

71. Lis A, Kowal M. Constituents of the essential oils from different organs of Artemisia campestris L. subsp. campestris. J Essent Oil Res. 2015;27(6):545-50.

72. Lis A, Kowal M, Kończak J. Chemical Composition Variability of the Herb Essential Oil in the Ontogenesis of Artemisia campestris subsp. campestris. Nat Prod Commun. 2015;10(10):1763-66.

73. Silvestre A, Silva A, Almeida L, Pereira C, Cavaleiro J. The essential oil of Artemisia campestris L. subsp. maritima Arcangelis. Acta Hortic. 1999;500:93-6.

74. Silva A, Seca A, Vasconcelos J, Cavaleiro J, Silvestre A, Domingues F, PascoalNeto C. Chemical composition of Artemisia campestris and Hibiscus cannabinus. In: Natural Products in the New Millennium: Prospects and Industrial Application. Berlin, Heidelberg: Springer; 2002. p. 47-57.

75. Mucciarelli M, Caramiello R, Maffei M, Chialva F. Essential oils from some Artemisia species growing spontaneously in North-West Italy. Flavour Fragr J. 1995;10(1):25-32.

76. Boligon AA, Machado MM, Athayde ML. Technical evaluation of antioxidant activity. Med. Chem. 2014;4:517-522.

77. Prior RL, Wu X, Schaich K. Standardized methods for the determination of antioxidant capacity and phenolics in foods and dietary supplements. J Agric Food Chem. 2005;53(10):4290-302.

78. Mekhfi H, El Haouari M, Legssyer A, Bnouham M, Aziz M, Atmani F, Remmal A, Ziyyat A. Platelet anti-aggregant property of some Moroccan medicinal plants. J Ethnopharmacol. 2004;94(2):317-22.

79. El Haouari M, Rosado JA. Platelet function in hypertension. Blood Cells Mol Dis. 2009:42(1):38-43.

80. Blann AD, Nadar S, Lip GY. Pharmacological modulation of platelet function in hypertension. Hypertension. 2003;42(1):1-7.

81. Savage B, Cattaneo M, Ruggeri ZM. Mechanisms of platelet aggregation. Curr Opin Hematol. 2001;8(5):270-76.

82. Sanders KM. Invited review: mechanisms of calcium handling in smooth muscles. J Appl Physiol. 2001;91(3):1438-49.

83. Vanhoutte PM, Rubanyi GM, Miller VM, Houston DS. Modulation of vascular smooth muscle contraction by the endothelium. Annu Rev Physiol. 1986; 48(1):307-20.

84. Furchgott RF, Vanhoutte PM. Endothelium-derived relaxing and contracting factors. FASEB J. 1989;3(9):2007-18. 
85. Furchgott RF. Role of endothelium in responses of vascular smooth muscle. Circ Res. 1983;53(5):557-73.

86. Furchgott RF, Zawadzki JV. The obligatory role of endothelial cells in the relaxation of arterial smooth muscle by acetylcholine. Nature. 1980; 288(5789):373-76.

87. Harvey RD. Muscarinic receptor agonists and antagonists: effects on cardiovascular function. In: Muscarinic Receptors, 208. New York: Springer; 2012. p. 299-316.

88. Kopincová J, Púzserová A, Bernátová I. Biochemical aspects of nitric oxide synthase feedback regulation by nitric oxide. Interdiscip Toxicol. 2011;4(2):63-8.

89. Tsai EJ, Kass DA. Cyclic GMP signaling in cardiovascular pathophysiology and therapeutics. Pharmacol Ther. 2009;122(3):216-38.

90. Giles TD, Sander GE, Nossaman BD, Kadowitz PJ. Impaired vasodilation in the pathogenesis of hypertension: focus on nitric oxide, endothelial-derived hyperpolarizing factors, and prostaglandins. J Clin Hypertens. 2012;14(4): 198-205.

91. Parkington HC, Coleman HA, Tare M. Prostacyclin and endothelium-dependent hyperpolarization. Pharmacol Res. 2004;49(6):509-14.

92. Sobey CG. Potassium channel function in vascular disease. Arterioscler Thromb Vasc Biol. 2001;21(1):28-38.

93. Xiong Z, Sperelakis N. Regulation of L-type calcium channels of vascular smooth muscle cells. J Mol Cell Cardiol. 1995;27(1):75-91.

94. Richard S. Vascular effects of calcium channel antagonists: new evidence. Drugs. 2005;65(2):1-10.

95. Adachi T. Modulation of vascular sarco/endoplasmic reticulum calcium ATPase in cardiovascular pathophysiology. Adv Pharmacol. 2010;59:165-95.

\section{Submit your next manuscript to BioMed Central} and we will help you at every step:

- We accept pre-submission inquiries

- Our selector tool helps you to find the most relevant journal

- We provide round the clock customer support

- Convenient online submission

- Thorough peer review

- Inclusion in PubMed and all major indexing services

- Maximum visibility for your research

Submit your manuscript at www.biomedcentral.com/submit 